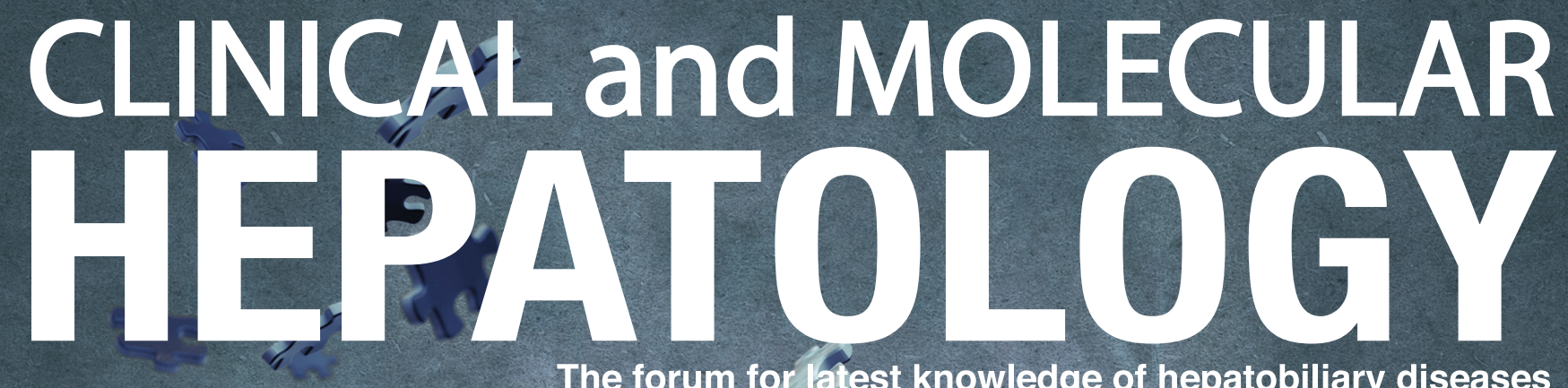

The forum for latest knowledge of hepatobiliary diseases

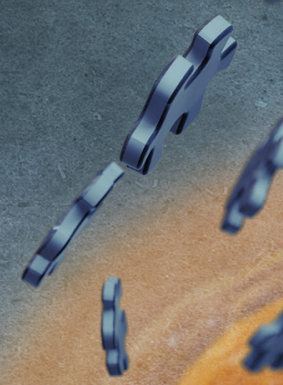

is

$$
\text { (n) }
$$

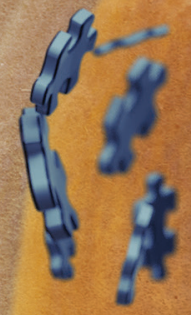

Fatty liver and risk of olementia

NAFLD increases a risk of siroke

DPP-4 inhibitor-specinic biornarkers in NAFID

LPS promotes HCC by NEE IS formation via TLRS4

CLIF-SOFA score and sepsis

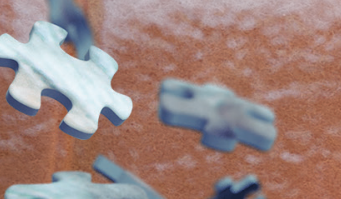




\title{
RNA interference as a novel treatment strategy for chronic hepatitis B infection
}

\author{
Rex Wan-Hin Hui', Lung-Yi Mak ${ }^{1,2}$, Wai-Kay Seto ${ }^{1,2}$, and Man-Fung Yuen ${ }^{1,2}$ \\ 'Department of Medicine, The University of Hong Kong; ${ }^{2}$ State Key Laboratory of Liver Research, The University of Hong Kong, \\ Hong Kong
}

Chronic hepatitis B (CHB) is a major cause of liver-related morbidity and mortality. Functional cure of CHB, defined as sustainable hepatitis B surface antigen ( $\mathrm{HBsAg}$ ) seroclearance, is associated with improved clinical outcomes. However, functional cure is rarely attainable by current treatment modalities. RNA interference (RNAi) by small-interfering RNA (siRNA) and anti-sense oligonucleotide (ASO) has been studied as a novel treatment strategy for CHB. RNAi targets post-transcriptional messenger RNAs and pregenomic RNAs to reduce hepatitis B virus (HBV) antigen production and viral replication. By reducing viral antigens, host immune reconstitution against HBV may also be attained. Phase I/II trials on siRNAs have demonstrated them to be safe and well-tolerated. siRNA is effective when given in monthly doses with different total number of doses according to different trial design, and can lead to sustainable dose-dependent mean $\mathrm{HBs} A g$ reduction by 2-2.5 log. Incidences of HBsAg seroclearance after siRNA therapy have also been reported. ASOs have also been studied in early phase trials, and a phase $\mathrm{lb}$ study using frequent dosing regimen within 4 weeks could achieve similar HBsAg reduction of 2 log from baseline. Given the established efficacy and safety of nucleos(t) ide analogues (NAs), future RNAi regimens will likely include NA backbone. While the current evidence on RNAi appears promising, it remains undetermined whether the potent HBsAg reduction by RNAi can result in a high rate of $\mathrm{HBsAg}$ seroclearance with durability. Data on RNAi from phase Ilb/III trials are keenly anticipated. (Clin Mol Hepatol 2022;28:408-424)

Keywords: Hepatitis B virus; Hepatitis B surface antigens; Small-interfering RNA; Anti-sense oligonucleotide; Messenger RNA

\section{BACKGROUND}

Chronic hepatitis B (CHB) affects over 290 million patients worldwide and is a major cause of liver-related morbidity and mortality.' Established treatment modalities for CHB include nucleos(t)ide analogues (NAs) and pegylated interferon. While current agents are effective in suppressing the viral load, complete cure and sterilization of hepatitis B virus (HBV) are not achievable due to persistence of covalently closed circular DNA (cccDNA) and viral integration into the host ge-

\footnotetext{
Corresponding author : Man-Fung Yuen

Department of Medicine, The University of Hong Kong, Queen Mary Hospital, Pokfulam Road, Hong Kong

Tel: +852-22553984, Fax: +852-28162863, E-mail: mfyuen@hkucc.hku.hk

https://orcid.org/0000-0001-7985-7725
}

\section{Wai-Kay Seto}

Department of Medicine, The University of Hong Kong, Queen Mary Hospital, Pokfulam Road, Hong Kong Tel: +852-22556979, Fax: +852-28725828, E-mail: wkseto@hku.hk 
nome. ${ }^{2}$ Chronic exposure to high levels of HBV antigens also lead to host immune dysfunction/anergy and result in inability of the immune system to clear the virus. ${ }^{2}$ Functional cure, defined as sustained loss of hepatitis B surface antigen (HB$\mathrm{sAg}$ ), is a favorable endpoint in $\mathrm{CHB}$ due to its association with fibrosis regression ${ }^{3}$ and reduced hepatocellular carcinoma risk. ${ }^{4}$ It is also regarded as a clinical indicator of adequate host immune control on $\mathrm{HBV}^{5}$

Multiple novel therapeutics, broadly classified as virus-targeting agents and immunomodulators, are being actively investigated as strategies for achieving functional cure. ${ }^{5}$ Virustargeting agents inhibit different steps of the HBV lifecycle and agents in development include: 1) entry inhibitors: which inhibit HBV docking and hepatocyte entry ${ }_{i}^{6}{ }^{2}$ ) polymerase inhibitors: which inhibit HBV polymerase competitively (conventional NAs) or non-competitively (novel active site polymerase inhibitor nucleotide); ${ }^{7}$ 3) RNA silencers: which inhibit HBV messenger RNA (mRNA) translation and viral protein production; ${ }^{8} 4$ ) capsid assembly modulators: which inhibit $\mathrm{HBV}$ nucleocapsid assembly and pregenomic RNA encapsidation; ${ }^{9}$ 5) viral protein export inhibitors: which inhibit HBV antigen release from hepatocytes; ${ }^{10,11}$ and 6) farnesoid $X$ receptor (FXR) agonist: which reverses the interaction between FXR and the HBV X protein to interfere with transcription regulation. ${ }^{12}$ Immunomodulators utilize an alternative strategy which is different from virus-targeting agents. Immunomodulators reconstitute the patient's immune system to induce responses against HBV. Immunomodulators that have been studied include toll-like receptor agonists, ${ }^{13}$ immune checkpoint inhibitors, ${ }^{14} \mathrm{~T}$-cell modulators, ${ }^{15}$ therapeutic vaccines, ${ }^{16}$ and recombinant immunoglobulins. ${ }^{17}$

Among the above therapeutic means, RNA interference (RNAi) was one of the earliest agents developed and has demonstrated promising results. ${ }^{5}$ RNAi involves the use of homologous nucleotide strands to target post-transcriptional HBV mRNA, which in turn inhibit downstream viral protein production. ${ }^{5}$ RNAi can suppress HBsAg to low levels, which is an important surrogate outcome that predicts HBsAg seroclearance. ${ }^{18}$ With HBsAg reduction through RNAi, T-cell aner- gy may be reversed and reconstitution of the host immune response may be achievable. This article will review the mechanisms and evidence on using RNAi in CHB.

\section{RNAi}

\section{Mechanism of RNAi}

In 1998, Fire et al..$^{19}$ first reported non-coding doublestranded RNA to have potent and specific effects on posttranscriptional gene silencing in Caenorhabditis elegans (roundworm). The non-coding double-stranded RNA was named small-interfering RNA (siRNA) and this phenomenon was termed RNAi. ${ }^{19}$

siRNA has a passenger strand (sense) and guide strand (antisense), with the guide strand being complementary to target mRNA. siRNA is taken into the cytoplasm via endocytosis, after which it interacts with Dicer (RNase III endonuclease), Argonaute (RNase) and transactivation response element RNA-binding protein (RNA-binding cofactor) to form the RNA-induced silencing complex loading complex (RLC). ${ }^{20}$ The RLC retains the siRNA guide strand and removes the passenger strand to form a mature RNA-induced silencing complex (RISC). RISC can subsequently bind to target mRNA that has complementary sequence to the siRNA guide strand. ${ }^{21}$

After binding, RISC induces gene silencing through a variety of mechanisms, which may vary between organisms. Argonaute-induced mRNA degradation is the most well-described, where Argonaute cleave the target mRNA between nucleotides 10 and 11 , inducing exonuclease degradation of the cleaved oligonucleotides. ${ }^{22}$ RISC can also directly inhibit RNA translation through deadenylation of the poly $(A)$ tail of mRNA, blocking protein interactions between initiation factors, and inducing premature termination of translation. ${ }^{23,24}$ Finally, RISC can induce formation of heterochromatin in the target DNA through histone methyltransferases to induce epigenetic changes. ${ }^{25} \mathrm{RISC}$ is a multiple turnover enzyme, hence a single siRNA can silent multiple mRNA transcripts af-

\footnotetext{
Abbreviations:

ALT, alanine aminotransferase; ASOs, antisense oligonucleotides; CCCDNA, covalently closed circular DNA; CHB, chronic hepatitis B; FXR, farnesoid X receptor; GalNAC, $\mathrm{N}$-acetylgalactosamine; HBeAg, hepatitis B e-antigen; HBsAg, hepatitis B surface antigen; HBV, hepatitis B virus; HIV, human immunodeficiency virus; mRNA, messenger RNA; NAs, nucleos(t)ide analogues; ORFs, open reading frames; RISC, RNA-induced silencing complex; RLC, RNA-induced silencing complex loading complex; RNAi, RNA interference; siRNA, small-interfering RNA
} 


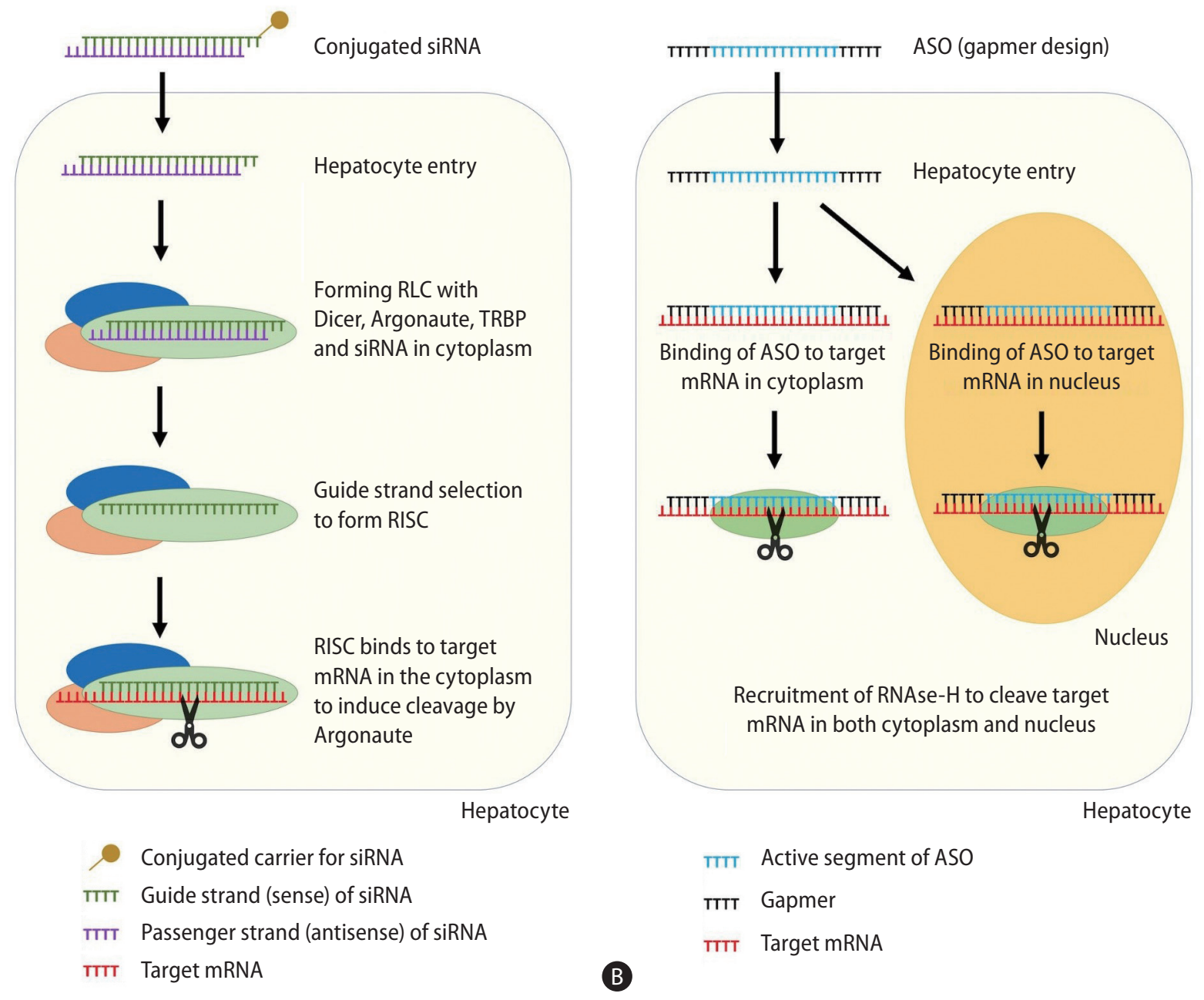

Figure 1. Mechanism of small-interfering RNA ( $\mathrm{A}$ ) and antisense oligonucleotides (B). siRNA, small-interfering RNA; RLC, RNA-induced silencing complex loading complex; TRBP, transactivation response element RNA-binding protein; RISC, RNA-induced silencing complex; mRNA, messenger RNA; ASO, antisense oligonucleotide.

ter activation into RISC. ${ }^{26}$ Figure 1 depicts the mechanism of RNAi.

\section{RNAi as a therapeutic strategy for viral infections}

RNAi is a versatile technique that can target any gene with an identifiable sequence, overcoming the challenge of selecting downstream "druggable" targets. Patisiran, an siRNA targeting hereditary transthyretin amyloidosis, became the first siRNA therapeutic approved by the US Food and Drug Administration in $2018 .{ }^{27}$ Since then, the field of siRNA therapeutics has been rapidly expanding. Due to the versatility of siRNA, its use is currently studied in a wide range of diseases including viral infections, genetic conditions, heart failure, chronic kidney disease, and malignancies. ${ }^{28}$ As a drug class, siRNAs have also demonstrated impressive safety data and are generally well-tolerated. ${ }^{28}$

At present, siRNA is studied in chronic viral infections that cannot be eliminated by current therapeutics, such as $\mathrm{CHB}^{8}$ and human immunodeficiency virus (HIV) infection. ${ }^{29,30}$ siRNA has also been studied in viruses that do not have effective treatment available, such as respiratory syncytial virus, ${ }^{31}$ poliovirus, ${ }^{32}$ and Ebola virus. ${ }^{33}$

A key consideration in developing siRNA antivirals involves appropriate sequence selection. The selected RNA sequence should be highly specific to conserved sequences in the targeted viral genome, such that pan-genotypic antiviral effects can be exerted. ${ }^{34}$ Specific siRNA sequences may also reduce off-target effects on the host genome that induce undesir- 


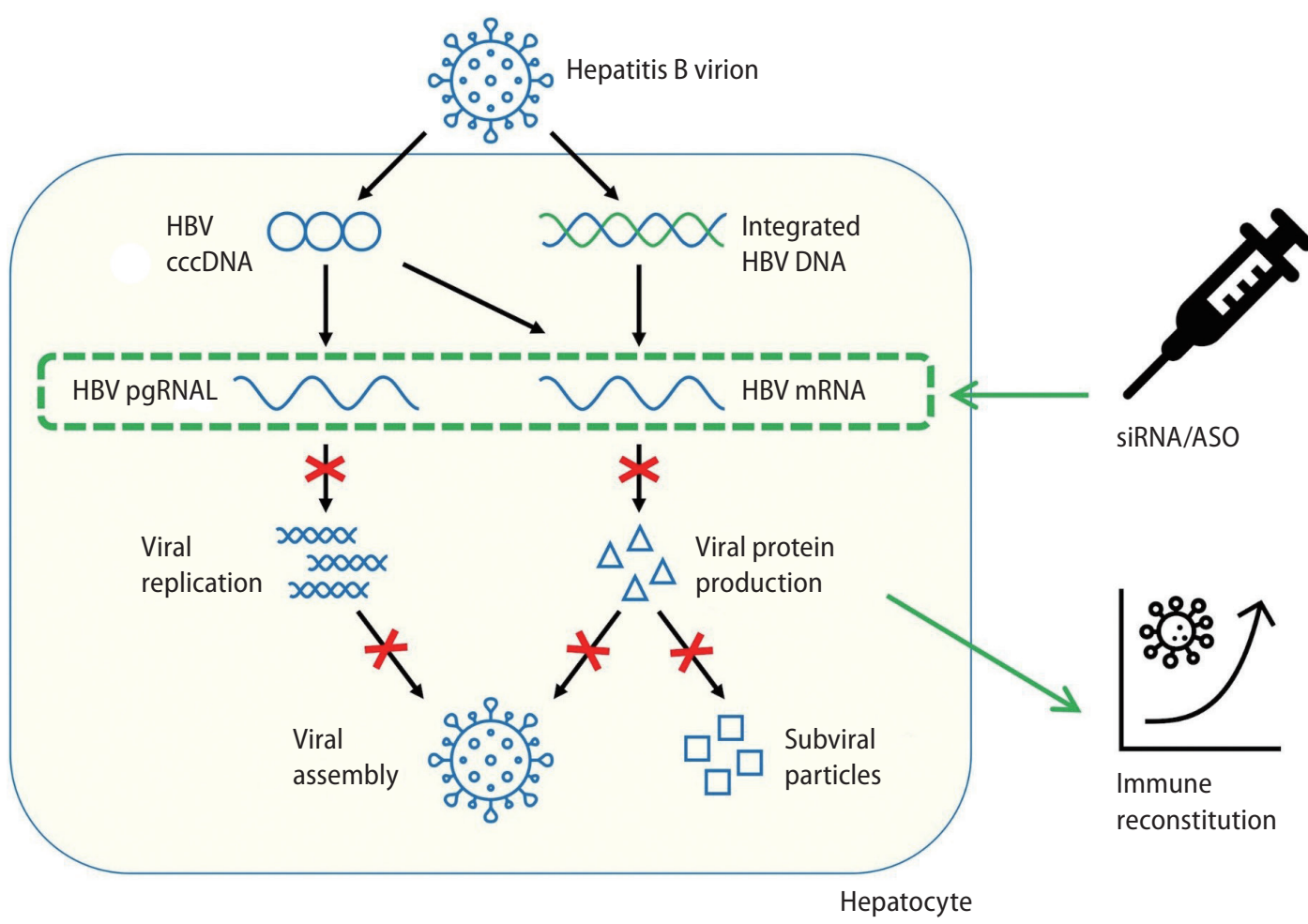

Figure 2. Mechanism of RNA interference as a treatment strategy in chronic hepatitis B. HBV, hepatitis B virus; cccDNA, covalently closed circular DNA; pgRNA, pregenomic RNA; mRNA, messenger RNA; siRNA, small-interfering RNA; ASO, antisense oligonucleotide.

able drug toxicity. ${ }^{35}$ The optimal length of siRNA is 21 nucleotides with two nucleotides overhanging on the $3^{\prime}$ end, as longer sequences increase the risk of off-target effects. ${ }^{36} \mathrm{Ad}$ vanced bioinformatics techniques and specialized software are utilized for filtering inappropriate sequences and predicting effective sequences. ${ }^{37}$

Structural optimization is critical for siRNA antivirals. Due to naturally occurring nucleases, unmodified siRNA is rapidly broken down in human serum. ${ }^{38}$ Furthermore, due to the presence of a phosphate backbone and anionic charge, unmodified siRNA is hydrophilic and cannot diffuse through negatively charged cell membranes..$^{39}$ Finally, siRNA has immune stimulatory effects and can induce unwanted nonspecific interferon responses through double-stranded RNAdependent protein kinase ${ }^{40}$ and toll-like receptors. ${ }^{41}$ Chemical modification of the siRNA phosphate backbone can tackle all three challenges of siRNA instability, cellular entry, and inadvertent immune activation. By replacing the 2 '- $\mathrm{OH}$ group by 2'-0-methyl or 2'-F-nucleotide on the phosphate backbone, siRNA can be protected from serum nucleases, ${ }^{42}$ has reduced off-target effects, ${ }^{43}$ has minimal unwanted immune stimula- tory responses, ${ }^{44}$ and at the same time, has increased potency by 500 -fold. ${ }^{45}$

Delivery systems are required to carry siRNA into target cells and both viral and non-viral vectors have been studied. Adenovirus vector is the most commonly used viral vector, as it is non-toxic, easy to produce, and adequate experience is available from its use in vaccines. ${ }^{46}$ Non-viral vectors, on the other hand, include polymers, aptamers, peptides, liposomes, antibodies and lipid nanoparticles. ${ }^{47}$ The choice of delivery system depends on the desired target of the siRNA. For example, $\mathrm{N}$-acetylgalactosamine (GalNAc) is ideal for liver-directing siRNA as GalNAc binds to Asialoglycoprotein receptors, a specific and abundant receptor in hepatocytes. ${ }^{48} \mathrm{Gal}-$ NAc-conjugation minimizes systemic siRNA exposure, reduces infusion reactions, lengthens dosing intervals, and enables administration through subcutaneous infusion. ${ }^{48}$

\section{Designing RNAi therapeutics for HBV}

$\mathrm{HBV}$ is characterized by its four open reading frames (ORFs) that encode for hepatitis B precore/core, polymerase, surface, 
and $\mathrm{X}$ proteins respectively. The four ORFs have overlapping sequences and have the same polyadenylation signal at the $3^{\prime}$ end in the core protein coding region. This enables interference of all four HBV transcripts with a single siRNA, reducing all downstream viral protein and pregenomic RNA production. Viral replication will therefore be reduced by siRNA, which may indirectly reduce the cccDNA reservoir. ${ }^{49}$ siRNA is hence able to directly or indirectly interfere with multiple steps of the viral lifecycle. Figure 2 depicts the mechanism of RNAi against HBV.

Viral mutation is a concern in designing siRNA against HBV, as a single base mismatch could lead to loss of siRNA effect. Rapid emergence of mutant strains after siRNA treatment has been reported in RNA viruses including $\mathrm{HIV}^{50}$ and hepatitis $\mathrm{C}$ virus. ${ }^{51} \mathrm{HBV}$, while being a DNA virus, requires reverse transcriptase for replication. As reverse transcriptase does not have proofreading capability, HBV has a mutation rate of $2 \times 10^{4}$ base substitutions/site/year, which is 100 times higher than other DNA viruses. ${ }^{52}$ Nonetheless, the mutation rate of HBV is still 100-1,000 times lower than that of RNA viruses. ${ }^{52}$ siRNA-induced mutants have not been reported in HBV, yet siRNA can exert selection pressure on preexisting resistant HBV quasispecies. ${ }^{53}$ Targeting functionally vital and conserved regions ${ }^{53}$ or using multiple siRNA triggers ${ }^{54}$ are essential in minimizing the potential impact of HBV mutants in siRNA therapy.

siRNA may also restore the host immune response against $\mathrm{HBV}$. A major contributor in the chronic persistence of HBV is host immune suppression after long term exposure to high levels of immune repressive viral antigens, particularly HBsAg. ${ }^{32} \mathrm{CHB}$ is associated with impairment of host immune pathways including Toll-like receptor signaling, ${ }^{55}$ immune checkpoint signalling, ${ }^{56}$ and increased immunosuppressive Tregulatory cells activity. ${ }^{57}$ These actions ultimately lead to reduction and dysfunction of HBV-specific T-cell clones, ${ }^{58,59}$ resulting in numerical and functional T-cell deficits against $\mathrm{HBV}$. Through its potent effect in reducing $\mathrm{HBV}$ viral antigens, siRNA may indirectly reconstitute the immune system. On one hand, long term viral suppression with NAs can only minimally reduce viral antigen levels as they inhibit the reverse transcriptase but cannot directly target HBV cccDNA. ${ }^{60,61}$ siRNA on the other hand, is predictably associated with more pronounced $\mathrm{HBsAg}$ reduction.

\section{Antisense oligonucleotides (ASOs), an alternative form of gene silencing}

Antisense oligonucleotide (ASO) is a related yet distinct drug class from siRNA. Like siRNA, ASO utilizes complementary nucleotide binding to exert post-transcriptional gene silencing on target mRNA (Fig. 1).

Key differences should be noted between siRNA and ASO (Table 1). First, siRNAs are double-stranded RNA with ideal length of 21 nucleotides plus two $3^{\prime}$ end overhanging nucleotides. In contrast, ASOs are single-stranded DNA of 15 to 25 nucleotides in length. ${ }^{62} \mathrm{ASO}$ s are designed as gapmers, with a central unmodified complementary DNA sequence flanked by modified RNA-like segments on both sides. Gapmer structure enhances the affinity of ASO to its target sequence and increases its resistance to nuclease degradation. ${ }^{63}$

Secondly, unmodified siRNA requires carriers for cellular entry, whereas unconjugated ASO is taken up into hepato-

Table 1. Differences between small-interfering RNA and antisense oligonucleotides

\begin{tabular}{|c|c|c|}
\hline & siRNA & ASO \\
\hline Structure & $\begin{array}{l}\text { Double-stranded RNA + two 3' end overhanging } \\
\text { nucleotides }\end{array}$ & $\begin{array}{l}\text { Single-stranded DNA + flanking by modified } \\
\text { RNA-like segments (gapmer) }\end{array}$ \\
\hline Ideal length & 21 nucleotides & $15-25$ nucleotides \\
\hline Cellular entry & $\begin{array}{l}\text { Requires conjugation to carrier for hepatocyte } \\
\text { uptake }\end{array}$ & $\begin{array}{l}\text { Can be taken into hepatocytes in unconjugated } \\
\text { form }\end{array}$ \\
\hline Accumulation & In endosomes & In cytoplasm \\
\hline Dosing frequency & Less frequent (monthly) & More frequent (weekly or biweekly) \\
\hline Target mRNA binding & Requires RISC formation & Can bind to target alone \\
\hline Primary gene silencing mechanism & Target RNA cleavage by Argonaute & Target RNA cleavage by RNAse-H \\
\hline
\end{tabular}

siRNA, small-interfering RNA; ASO, antisense oligonucleotide; mRNA, messenger RNA; RISC, RNA-induced silencing complex. 
cytes through receptor mediated pathways. ${ }^{64}$ After cellular entry, siRNA accumulates in endosomes and requires less frequent dosing, ${ }^{65,66}$ whereas ASO accumulates in cytoplasm and requires more frequent dosing. While conjugation to carriers is not a necessity for ASO, GalNAc-conjugation in ASO can enhance hepatocyte uptake and reduce systemic exposure, similar as the effect of GalNAc-conjugation in siRNA. ${ }^{68}$

Thirdly, siRNA requires RISC formation for target mRNA binding, as passenger strand removal is integral in the exposure of complementary nucleotides on the guide strand, ${ }^{21}$ whereas ASO can bind to target mRNA alone.

Fourthly, siRNA and ASO have distinct mechanisms of gene silencing. siRNA mediates its action through RISC as described above. In contrast, ASO most commonly mediates its action through recruitment of RNase-H (a family of endonucleases) in both the cytoplasm and nucleus to cleave target RNA. ${ }^{69}$ ASO may also inhibit RNA translation through inhibit- ing $5^{\prime}$ cap formation ${ }^{70}$ or blocking ribosomal subunit attachment. $^{71}$

ASO has been studied as a novel therapeutic in $\mathrm{CHB}_{1}{ }^{72}$ and the evidence on ASO will be discussed below.

\section{PRECLINICAL AND CLINICAL EVIDENCE IN CHB}

Wooddell et al. ${ }^{73}$ first reported the efficacy of siRNA in suppressing HBV in animal models. A single dose of ARC-520 induced $3.0 \log \mathrm{IU} / \mathrm{mL}$ HBsAg reduction in mice ${ }^{73}$ and $2.7 \log$ $\mathrm{IU} / \mathrm{mL} \mathrm{HBsAg}$ reduction in hepatitis $B$ e-antigen ( $\mathrm{HBeAg}$ )positive chimpanzees. ${ }^{74}$ However, $\mathrm{HBsAg}$ reduction was comparatively lower in $\mathrm{HBeAg}$-negative chimpanzees $(0.9 \mathrm{log} \mathrm{lU} / \mathrm{mL})$. The discrepancy in $\mathrm{HBsAg}$ responses between $\mathrm{HBeAg}$-positive and negative subjects was an unexpected finding. The investigators proceeded with a range of genome and animal

Table 2. RNA silencers in development

\begin{tabular}{|c|c|c|c|}
\hline & Agent & Stage of development & Clinical trial number \\
\hline \multirow[t]{8}{*}{ siRNA } & ARC-520 & Phase II & Discontinued \\
\hline & ARB-1467 & Phase II & Discontinued \\
\hline & AB-729 & Phase II & NCT04820686 \\
\hline & RG-6346 & Phase II & NCT03772249 \\
\hline & VIR-2218 & Phase II & NCT03672188 \\
\hline & JNJ-3989 & Phase II & NCT04129554 \\
\hline & ALG-125755 & Preclinical & $\begin{array}{l}\text { Planned to enter } \\
\text { clinical trials in } 2022\end{array}$ \\
\hline & ALG-125918 & Preclinical & / \\
\hline \multirow[t]{4}{*}{ ASO } & Bepirovirsen & Phase II & NCT02981602 \\
\hline & GSK3389404 & Phase II & NCT03020745 \\
\hline & R07062931 & Phase I & NCT03038113 \\
\hline & ALG-020572 & Phase I & NCT05001022 \\
\hline \multirow[t]{9}{*}{ Combination therapy } & AB-729 (siRNA) + capsid assembly modulator (vebicorvir) & Phase II & NCT04820686 \\
\hline & RG-6346 (siRNA) + pegylated interferon & Phase II & NCT04225715 \\
\hline & RG-6346 (siRNA) + capsid assembly modulator (RO7049389) & Phase II & NCT04225715 \\
\hline & RG-6346 (siRNA) + toll-like receptor agonist (R07020531) & Phase II & NCT04225715 \\
\hline & VIR-2218 (siRNA) + pegylated interferon & Phase II & NCT04412863 \\
\hline & JNJ-3989 (siRNA) + capsid assembly modulator (JNJ-6379) & Phase II & NCT03982186 \\
\hline & GSK3389404 (ASO) + pegylated interferon & Phase II & NCT04676724 \\
\hline & ALG-125755 (siRNA) + ALG-020572 (ASO) & Preclinical & / \\
\hline & $\begin{array}{r}\text { ALG-125903 (siRNA) + ALG-020579 (ASO) + ALG-010133 } \\
\text { (HBsAg transport inhibiting oligonucleotide polymer) }\end{array}$ & Preclinical & / \\
\hline
\end{tabular}

siRNA, small-interfering RNA; ASO, antisense oligonucleotide; $\mathrm{HBsAg}$, hepatitis B surface antigen. 
Table 3. Effects of small-interfering RNA on hepatitis B surface antigen in clinical trials

\begin{tabular}{|c|c|c|c|c|}
\hline Agent & $\begin{array}{l}\text { siRNA } \\
\text { target }\end{array}$ & Carrier & Treatment regimen & Efficacy* \\
\hline \multirow[t]{3}{*}{ ARC-520 } & \multirow{3}{*}{$\begin{array}{l}2 \text { triggers } \\
\text { targeting } \\
\text { the } X \\
\text { open } \\
\text { reading } \\
\text { frame }\end{array}$} & \multirow[t]{3}{*}{ Cholesterol } & $4 \mathrm{mg} / \mathrm{kg} ;$ single dose ${ }^{74}$ & $\begin{array}{l}0.3 \mathrm{log} \mathrm{IU} / \mathrm{mL} \mathrm{HBsAg} \text { reduction (NA treated } \mathrm{HBeAg}- \\
\text { negative patients); } 1.4 \mathrm{log} \mathrm{IU} / \mathrm{mL} \text { HBsAg reduction } \\
\text { (treatment naïve } \mathrm{HBeAg} \text {-positive patients) }\end{array}$ \\
\hline & & & $2 \mathrm{mg} / \mathrm{kg} ; \mathrm{Q} 1$ month $\times 4$ doses $^{82}$ & $\begin{array}{l}0.54 \mathrm{log} \mathrm{IU} / \mathrm{mL} \mathrm{HBsAg} \text { reduction (HBeAg positive } \\
\text { patients); } 0.38 \text { log IU } / \mathrm{mL} \text { HBsAg reduction (HBeAg } \\
\text { negative patients) }\end{array}$ \\
\hline & & & $4 \mathrm{mg} / \mathrm{kg} ; \mathrm{Q} 1 \mathrm{month}$ for up to 9 doses $^{83,+}$ & $\begin{array}{l}\text { 2.6 log IU/mL HBsAg reduction in } 2 \text { patients and } \\
\text { HBsAg seroclearance in } 1 \text { patient (HBeAg positive } \\
\text { patients); } 0.4 \mathrm{log} \mathrm{IU} / \mathrm{mL} \text { HBsAg reduction in } \\
4 \text { patients and HBsAg seroclearance in } 1 \text { patient } \\
\text { (HBeAg negative patients) }\end{array}$ \\
\hline \multirow[t]{3}{*}{ ARB-1467 } & \multirow{3}{*}{$\begin{array}{l}3 \text { triggers } \\
\text { targeting } \\
\text { the } S \text { and } \\
\text { X open } \\
\text { reading } \\
\text { frames }\end{array}$} & \multirow{3}{*}{$\begin{array}{l}\text { Lipid } \\
\text { nanoparticles }\end{array}$} & $0.2 \mathrm{mg} / \mathrm{kg} ; \mathrm{Q} 1$ month $\times 3$ doses $^{76}$ & $0.6 \log \mathrm{IU} / \mathrm{mL} \mathrm{HBsAg}$ reduction \\
\hline & & & $0.4 \mathrm{mg} / \mathrm{kg} ; \mathrm{Q} 1 \mathrm{month} \times 3$ doses $^{76}$ & $\begin{array}{l}0.7 \mathrm{log} \mathrm{IU} / \mathrm{mL} \mathrm{HBsAg} \text { reduction (HBeAg-positive } \\
\text { patients); } 0.9 \mathrm{log} \mathrm{IU} / \mathrm{mL} \mathrm{HBsAg} \text { reduction (HBeAg- } \\
\text { negative patients) }\end{array}$ \\
\hline & & & $0.4 \mathrm{mg} / \mathrm{kg} ; \mathrm{Q} 2$ weeks $\times 5$ doses $^{84}$ & Maximum individual $\mathrm{HBsAg}$ reduction of $2.7 \mathrm{log} \mathrm{IU} / \mathrm{mL}$ \\
\hline \multirow[t]{4}{*}{ AB-729 } & \multirow{4}{*}{$\begin{array}{l}1 \text { trigger } \\
\text { targeting } \\
\text { the } X \\
\text { open } \\
\text { reading } \\
\text { frame }\end{array}$} & \multirow[t]{4}{*}{ GalNAc } & $\begin{array}{l}60 \mathrm{mg} ; \mathrm{Q} 1 \text { month } \times 6 \text { doses; followed } \\
\text { by Q3 months } \times 2 \text { doses }^{86}\end{array}$ & $1.89 \mathrm{log} \mathrm{IU} / \mathrm{mL}$ HBsAg reduction \\
\hline & & & 60 mg; Q2 months $\times 6$ doses $^{86}$ & $1.90 \log \mathrm{IU} / \mathrm{mL} \mathrm{HBsAg}$ reduction \\
\hline & & & 90 mg; Q2 months $\times 6$ doses $^{86}$ & $2.16 \log \mathrm{IU} / \mathrm{mL} \mathrm{HBs} A g$ reduction \\
\hline & & & $90 \mathrm{mg}$; Q3 months $\times 4$ doses $^{86}$ & $1.86 \log \mathrm{IU} / \mathrm{mL}$ HBsAg reduction \\
\hline \multirow[t]{3}{*}{ RG-6346 } & \multirow{3}{*}{$\begin{array}{l}1 \text { trigger } \\
\text { targeting } \\
\text { the } S \\
\text { open } \\
\text { reading } \\
\text { frame }\end{array}$} & \multirow[t]{3}{*}{ GalNAc } & $1.5 \mathrm{mg} / \mathrm{kg} ; \mathrm{Q} 1$ month $\times 4$ doses $^{89}$ & $1.64 \mathrm{log} \mathrm{IU} / \mathrm{mL} \mathrm{HBsAg}$ reduction \\
\hline & & & $3.0 \mathrm{mg} / \mathrm{kg} ; \mathrm{Q} 1$ month $\times 4$ doses $^{89}$ & $\begin{array}{l}1.91 \log \mathrm{IU} / \mathrm{mL} \mathrm{HBsAg} \text { reduction (NA treated patients); } \\
1.02 \mathrm{log} \mathrm{IU} / \mathrm{mL} \text { HBsAg reduction (treatment naïve } \\
\text { patients) }\end{array}$ \\
\hline & & & $6.0 \mathrm{mg} / \mathrm{kg} ; \mathrm{Q} 1$ month $\times 4$ doses $^{89}$ & $1.87 \log \mathrm{IU} / \mathrm{mL}$ HBsAg reduction \\
\hline \multirow[t]{5}{*}{ VIR-2218 } & \multirow{5}{*}{$\begin{array}{l}1 \text { trigger } \\
\text { targeting } \\
\text { the } X \\
\text { open } \\
\text { reading } \\
\text { frame }\end{array}$} & \multirow[t]{5}{*}{ GalNAc } & $\begin{array}{l}20 \mathrm{mg} \text { or } 50 \mathrm{mg} \text { or } 100 \mathrm{mg} \text { or } 200 \mathrm{mg} \\
\text { Q1 month } \times 2 \text { doses }^{75}\end{array}$ & $\begin{array}{l}70.8 \% \text { of patients had more than } 1.0 \mathrm{log} \mathrm{IU} / \mathrm{mL} \\
\text { reduction in } \mathrm{HBsAg} \text {. Among patients who achieved } \\
\text { more than } 1.0 \mathrm{log} \mathrm{IU} / \mathrm{mL}, 70.6 \% \text { of patients } \\
\text { achieved } \mathrm{HBsAg} \text { nadir of below } 100 \mathrm{IU} / \mathrm{mL}\end{array}$ \\
\hline & & & $200 \mathrm{mg} ; \mathrm{Q} 1$ month $\times 6$ doses $^{95}$ & $1.89 \log \mathrm{IU} / \mathrm{mL} \mathrm{HBsAg}$ reduction \\
\hline & & & $\begin{array}{l}200 \text { mg; Q1 month } \times 6 \text { doses; } \\
\text { combined with Q1 week pegylated } \\
\text { interferon alpha-2a for } 12 \text { doses } \\
\text { starting from week } 12^{95}\end{array}$ & $2.03 \mathrm{log} \mathrm{IU} / \mathrm{mL} \mathrm{HBsAg}$ reduction \\
\hline & & & $\begin{array}{l}200 \text { mg; Q1 month } \times 6 \text { doses; } \\
\text { combined with Q1 week pegylated } \\
\text { interferon alpha-2a for } 24 \text { doses }^{95}\end{array}$ & $2.55 \log \mathrm{IU} / \mathrm{mL}$ HBsAg reduction \\
\hline & & & $\begin{array}{l}200 \mathrm{mg} \text {; Q1 month } \times 6 \text { doses; } \\
\text { combined with Q1 week pegylated } \\
\text { interferon alpha-2a for } 48 \text { doses }^{95}\end{array}$ & $2.30 \log \mathrm{IU} / \mathrm{mL}$ HBsAg reduction \\
\hline \multirow[t]{5}{*}{ JNJ-3989 } & \multirow{5}{*}{$\begin{array}{l}2 \text { triggers } \\
\text { targeting } \\
\text { the } S \text { and } \\
X \text { open } \\
\text { reading } \\
\text { frames }\end{array}$} & \multirow[t]{5}{*}{ GalNAc } & $\begin{array}{l}100 \mathrm{mg} \text { or } 200 \mathrm{mg} \text { or } 300 \mathrm{mg} \text { or } 400 \\
\mathrm{mg} \text {; } 1 \text { month } \times 3 \text { doses }\end{array}$ & $1.93 \mathrm{log} \mathrm{IU} / \mathrm{mL} \mathrm{HBsAg}$ reduction \\
\hline & & & $40 \mathrm{mg} ; \mathrm{Q} 1$ month $\times 12$ doses $^{96}$ & $1.5 \log \mathrm{IU} / \mathrm{mL} \mathrm{HBsAg}$ reduction \\
\hline & & & $\begin{array}{l}100 \text { mg; Q1 month } \times 12 \text { doses; } \\
\text { combined with JNJ-6379 (capsid } \\
\text { assembly modulator) }^{96}\end{array}$ & $1.8 \mathrm{log} \mathrm{IU} / \mathrm{mL}$ HBsAg reduction \\
\hline & & & $100 \mathrm{mg} ; \mathrm{Q} 1$ month $\times 12$ doses $^{96}$ & $2.1 \log \mathrm{IU} / \mathrm{mL} H B s A g$ reduction \\
\hline & & & $200 \mathrm{mg} ; \mathrm{Q} 1$ month $\times 12$ doses $^{96}$ & $2.6 \log \mathrm{IU} / \mathrm{mL} \mathrm{HBs} A g$ reduction \\
\hline
\end{tabular}

siRNA, small-interfering RNA; HBsAg, hepatitis B surface antigen; NA, nucleos(t)ide analogue; HBeAg, hepatitis B e-antigen; GalNAc, $\mathrm{N}$-acetylgalactosamine.

*HBsAg reductions depicted as mean log IU/mL unless otherwise specified.

${ }^{\dagger}$ Number of doses received varied from 4-9 doses, as the trial was terminated prior to completion. 
experiments, which demonstrated that $\mathrm{HBsAg}$ was not only expressed from HBV ccCDNA, but can also be produced from integrated HBV DNA. As ARC-520 was designed to target sequences between DR1 and DR2 regions of HBV (sequences commonly lost during HBV integration), it was unable to target HBV integrants, leading to differential responses in HBeAg-positive and negative subjects. ${ }^{74}$ Newer generation siRNA is designed to target transcripts upstream of integration hotspots ${ }^{75}$ or have multiple triggers, ${ }^{76,77}$ enabling targeting of all $\mathrm{HBV}$ transcripts from ccCDNA and HBV integrants.

After ARC-520, a range of newer RNA silencers have demonstrated promising data in in-vitro and in-vivo studies, ${ }^{78-80}$ and they have already entered clinical trials (Table 2). $\mathrm{HBsAg}$ suppression is the key outcome measured in the trials and the results are summarized below (Table 3).

\section{ARC-520}

As already described above, ARC-520 is the first-in-class siRNA for CHB. It contains two siRNA triggers targeting overlapping regions in the $\mathrm{X} O R F$ of $\mathrm{HBV}$ cccDNA. It is conjugated to cholesterol and is administered intravenously. Early safety studies demonstrated that adverse events were comparable in ARC-520 and placebo groups, with no serious adverse events noted. ${ }^{81}$

The Heparc-2001 trial was a phase II trial that tested the efficacy of a single dose of ARC-520 in CHB patients. Four arms of the trial consisted of HBeAg-negative NA treated patients who received ARC-520 at doses ranging from $1-4 \mathrm{mg} / \mathrm{kg}$. Serum HBsAg declined within the first eight days of ARC-520 dosing. $\mathrm{HBsAg}$ responses correlated with ARC-520 dosage and the $4 \mathrm{mg} / \mathrm{kg}$ group had $\mathrm{HBsAg}$ reduction by $0.3 \mathrm{log} \mathrm{IU} / \mathrm{mL}^{74}$ In a separate arm of treatment-naïve patients (six HBeAgpositive and six $\mathrm{HBeAg}$-negative), a single dose of $4 \mathrm{mg} / \mathrm{kg}$ ARC-520 was started concurrently with entecavir. Excluding one HBeAg-positive patient who had low baseline HBeAg level and was considered to be transitioning to $\mathrm{HBeAg}$-negative status, the $\mathrm{HBeAg}$-positive group had $\mathrm{HBsAg}$ reduction by $1.4 \log \mathrm{IU} / \mathrm{mL}$. In contrast, HBeAg-negative treatment-naïve patients did not have significant $\mathrm{HBsAg}$ reduction. ${ }^{74} \mathrm{As}$ discussed above, this differential response in $\mathrm{HBeAg}$-positive and negative patients is attributable to the inability of ARC520 in targeting HBV integrants.

In the Heparc-2002 and Heparc-2003 trials, patients on NAs were randomized to receive four monthly doses of $2 \mathrm{mg} / \mathrm{kg}$
ARC-520 or placebo. ARC-520 led to HBsAg reduction by 0.54 $\log \mathrm{IU} / \mathrm{mL}$ and $0.38 \log \mathrm{IU} / \mathrm{mL}$ in $\mathrm{HBeAg}$-positive and negative patients respectively. The HBsAg response was sustainable for over 85 days post-treatment. ${ }^{82}$

Eight patients (three HBeAg positive and five HBeAg negative) from the Heparc-2001 trial were recruited to an extension trial. The patients received up to nine monthly doses of $4 \mathrm{mg} / \mathrm{kg}$ ARC-520 around 8 to 10 months after initial dosing and were followed up for up to 33 months afterwards. Among $\mathrm{HBeAg}$-positive patients, one patient achieved HBsAg seroclearance, whereas the other two patients had HBsAg reduction of $1.7 \mathrm{log} \mathrm{IU} / \mathrm{mL}$ and $3.5 \mathrm{log} \mathrm{IU} / \mathrm{mL}$ from baseline respectively. Among $\mathrm{HBeAg}$-negative patients, one patient achieved $\mathrm{HBsAg}$ seroclearance, whereas the other patients had a mean $\mathrm{HBsAg}$ reduction of $0.4 \mathrm{log} \mathrm{IU} / \mathrm{mL}$ from baseline. The HBsAg reduction was sustainable for up to 33 months after end of treatment. ${ }^{83}$

The development of ARC-520 was terminated in November 2016, as incidences of mortality induced by the excipient of ARC-520 (not the active siRNA component) in non-human primates were reported.

\section{ARB-1467}

ARB-1467 has three siRNA triggers targeting the HBV S and $X$ ORFs. It is delivered via lipid nanoparticles and is administered intravenously. In a 12-week trial on NA treated patients, $0.2 \mathrm{mg} / \mathrm{kg}$ or $0.4 \mathrm{mg} / \mathrm{kg}$ ARB-1467 was administered monthly for three doses, and mean HBsAg reduction of 0.6 to $0.9 \mathrm{log}$ $\mathrm{IU} / \mathrm{mL}$ was achieved. HBsAg reduction was sustained at end of follow-up (12 weeks). In the trial arms receiving $0.4 \mathrm{mg} / \mathrm{kg}$ ARB-1467, 45.5\% of patients (five out of 11) achieved greater than $1 \mathrm{log} \mathrm{IU} / \mathrm{mL}$ HBsAg reduction. ARB-1467 was well-tolerated, with mild injection reactions being the most commonly reported adverse event. ${ }^{76}$

Due to the modest effect of monthly ARB-1467 on HBsAg decline, biweekly dosing of ARB-1467 was tested. In a second part of the ARB-1467 trial, 12 NA treated patients received five doses of biweekly ARB-1467. When compared with monthly dosing, patients on biweekly dosing had a greater magnitude of $\mathrm{HBsAg}$ reduction, achieving maximum individual $\mathrm{HBsAg}$ decline of $2.7 \mathrm{log} \mathrm{IU} / \mathrm{mL}$. HBsAg reduction was sustainable at 10 weeks. ${ }^{84}$

The development of ARB-1467 was discontinued in March 2019, as the sponsor aimed to shift their focus to their newer 
siRNA product AB-729. ${ }^{85}$

\section{AB-729}

AB-729 is a subcutaneous GalNAc-conjugated siRNA with a single trigger targeting the HBV $X$ protein. A phase II multiarm trial assessed the effects of AB-729 at different doses (60 $\mathrm{mg}$ or $90 \mathrm{mg}$ ) and dosing intervals (4-weekly, 8-weekly, or 12-weekly dosing for 24 weeks, followed by extension of dosing every 8 or 12 weeks) in NA treated patients. HBsAg reduction ranged from 1.86 to $2.16 \mathrm{log} \mathrm{IU} / \mathrm{mL}$ in different trial arms, and the HBsAg decline was sustained up to 48 weeks. ${ }^{86}$ Across the treatment arms, over $70 \%$ of patients achieved $\mathrm{HBsAg}$ below $100 \mathrm{IU} / \mathrm{mL}$. HBsAg reduction also correlated with reduction of circulating HBV RNA and HBsAg isoforms, ${ }^{87}$ and was associated with an increase in HBV-specific T-cell activation markers. ${ }^{88}$ Patients on AB-729 had an increase in interferon-gamma producing HBV specific T-cells and had transient alanine aminotransferase (ALT) flares that correlated with $\mathrm{HBsAg}$ decline. These findings support the role of $A B-$ 729 in inducing immune reconstitution against $\mathrm{HBV}^{87,88}$ Injection site reactions were common in AB-729, yet no serious adverse events, trial discontinuations or deaths were reported.

\section{RG-6346}

RG-6346 is a subcutaneous GalNAc-conjugated siRNA with a single trigger targeting the HBV S ORF. In a phase Ila trial, NA treated patients received four monthly doses of RG-6346. The mean HBsAg reduction were $1.64 \log \mathrm{IU} / \mathrm{mL}, 1.91 \log \mathrm{IU} / \mathrm{mL}$ and $1.87 \mathrm{log} \mathrm{IU} / \mathrm{mL}$ in the $1.5 \mathrm{mg} / \mathrm{kg}, 3.0 \mathrm{mg} / \mathrm{kg}$ or $6.0 \mathrm{mg} / \mathrm{kg}$ RG-6346 arms respectively. Across treatment arms, $92 \%$ of patients achieved more than $1 \mathrm{log} \mathrm{IU} / \mathrm{mL} \mathrm{HBsAg}$ reduction and $58 \%$ of patients achieved HBsAg below $100 \mathrm{IU} / \mathrm{mL}$. An additional NA naïve arm achieved $\mathrm{HBsAg}$ reduction of 1.02 $\log \mathrm{IU} / \mathrm{mL}$ with $3.0 \mathrm{mg} / \mathrm{kg}$ RG-6346. The HBsAg suppression was sustained for up to 64 weeks. RG-6346 was associated with self-resolving ALT flares that corresponded with declining $\mathrm{HBsAg}$, suggesting treatment-induced immune reconstitution. Injection site reactions and flu-like symptoms were common adverse events in RG-6346. ${ }^{89}$

\section{VIR-2218}

VIR-2218 is a subcutaneous GalNAc-conjugated siRNA with a single trigger targeting the HBV X ORF. In a 48-week trial on NA treated patients, two monthly doses of VIR-2218 in the doses of $20 \mathrm{mg}, 50 \mathrm{mg}, 100 \mathrm{mg}$, or $200 \mathrm{mg}$ were given. Across the treatment arms, $70.8 \%$ of patients had more than 1 $\log \mathrm{IU} / \mathrm{mL}$ HBsAg reduction. Among patients who achieved 1 $\log \mathrm{IU} / \mathrm{mL} \mathrm{HBsAg}$ reduction, $70.6 \%$ of patients achieved HBsAg below $100 \mathrm{IU} / \mathrm{mL}$. Suppression of HBsAg below $100 \mathrm{IU} / \mathrm{mL}$ was not sustainable at 48 weeks in the $20 \mathrm{mg}$ and $50 \mathrm{mg}$ VIR2218 groups, whereas the response was sustained in $36.4 \%$ of patients in the $100 \mathrm{mg}$ and $200 \mathrm{mg}$ VIR-2218 groups. VIR2218 had a favorable safety profile, with headache being its most common side effect. ${ }^{75}$

\section{JNJ-3989}

JNJ-3989 is a subcutaneous GalNAc-conjugated siRNA with two triggers targeting the HBV $X$ and $S$ regions. In a phase II trial that recruited both NA treated and treatment-naiive patients, 3 monthly doses of JNJ-3989 at doses ranging from $100 \mathrm{mg}$ to $400 \mathrm{mg}$ were given, with NAs given concurrently with JNJ-3989 in the treatment-naive group. Across the treatment arms, a mean $\mathrm{HBsAg}$ reduction by $1.93 \mathrm{log} \mathrm{IU} / \mathrm{mL}$ along with decline in HBeAg and HBV RNA was documented. 97.5\% of patients across the treatment arms achieved more than $1 \log \mathrm{IU} / \mathrm{mL}$ HBsAg reduction, and the changes were sustained at 24 weeks. $^{77}$

\section{Agents in preclinical phase}

ALG-125918 is an siRNA designed with a novel 5' cap phosphate mimic that enhances siRNA loading and cleavage efficiency. A single dose of $5 \mathrm{mg} / \mathrm{kg}$ ALG-125918 led to maximum $\mathrm{HBsAg}$ reduction by $1.5 \mathrm{log} \mathrm{IU} / \mathrm{mL}$ in mice, which was sustainable for 90 days. $^{90}$ The development of ALG-125918 is ongoing.

ALG-125755 is a subcutaneous GalNAc-conjugated siRNA with a single trigger targeting the $S$ ORF. A single dose of 5 $\mathrm{mg} / \mathrm{kg}$ ALG-125755 led to HBsAg reduction by $1.5 \mathrm{log} \mathrm{IU} / \mathrm{mL}$ in mice, and the effect was sustained at 6 weeks. ${ }^{91}$ ALG125755 will enter clinical trials in early $2022 .{ }^{92}$

\section{Antisense oligonucleotides}

This section will summarize the clinical evidence on ASO (Table 4). 
Table 4. Effects of antisense oligonucleotides on hepatitis B surface antigen in clinical trials

\begin{tabular}{|c|c|c|c|}
\hline Agent & Carrier & Treatment regimen & Efficacy* \\
\hline \multirow[t]{4}{*}{ R07062931 } & GalNAC & $3.0 \mathrm{mg} / \mathrm{kg} ; \mathrm{Q} 1$ week $\times 5$ doses $^{68}$ & $0.50 \log \mathrm{IU} / \mathrm{mL} \mathrm{HBsAg}$ reduction \\
\hline & & $3.0 \mathrm{mg} / \mathrm{kg} ; \mathrm{Q} 2$ weeks $\times 3$ doses $^{68}$ & $0.39 \mathrm{log} \mathrm{IU} / \mathrm{mL} \mathrm{HBsAg}$ reduction \\
\hline & & $3.0 \mathrm{mg} / \mathrm{kg} ; \mathrm{Q} 4$ weeks $\times 2$ doses $^{68}$ & $0.28 \log \mathrm{IU} / \mathrm{mL} \mathrm{HBs} A g$ reduction \\
\hline & & $4.0 \mathrm{mg} / \mathrm{kg} ; \mathrm{Q} 4$ weeks $\times 2$ doses $^{68}$ & $0.34 \log \mathrm{IU} / \mathrm{mL} \mathrm{HBs} A g$ reduction \\
\hline \multirow[t]{3}{*}{ GSK3389404 } & GaINAC & $60 \mathrm{mg} ; \mathrm{Q} 1$ week $\times 12$ doses $^{93}$ & $0.34 \log \mathrm{IU} / \mathrm{mL} \mathrm{HBs} A \mathrm{~g}$ reduction \\
\hline & & $120 \mathrm{mg}$; Q1 week $\times 12$ doses $^{93}$ & $0.75 \log \mathrm{IU} / \mathrm{mL} \mathrm{HBsAg}$ reduction \\
\hline & & 120 mg; Q2 weeks $\times 6$ doses ${ }^{93}$ & $0.44 \log \mathrm{IU} / \mathrm{mL} \mathrm{HBsAg}$ reduction \\
\hline \multirow[t]{2}{*}{ Bepirovirsen } & Unconjugated & $\begin{array}{l}150 \text { mg; } 2 \text { times per week } \times 2 \text { doses; } \\
\text { then Q1 week } \times 2 \text { doses }^{94}\end{array}$ & $0.50 \log \mathrm{IU} / \mathrm{mL} \mathrm{HBsAg}$ reduction (treatment-naïve patients) \\
\hline & & $\begin{array}{l}300 \mathrm{mg} ; 2 \text { times per week } \times 2 \text { doses; } \\
\text { then } \mathrm{Q} 1 \text { week } \times 2 \text { doses }^{94}\end{array}$ & $\begin{array}{l}1.56 \log \mathrm{IU} / \mathrm{mL} \text { HBsAg reduction (treatment-naïve patients); } \\
1.99 \mathrm{log} \mathrm{IU} / \mathrm{mL} \text { HBsAg reduction (NA treated patients) }\end{array}$ \\
\hline
\end{tabular}

GaINAc, N-acetylgalactosamine; HBsAg, hepatitis B surface antigen; NA, nucleos(t)ide analogue.

*HBsAg reductions depicted as mean log IU/mL unless otherwise specified.

RO7062931 is a subcutaneous GalNAc-conjugated gapmer ASO targeting a highly conserved sequence in the shared $3^{\prime}$ region. In a phase I trial, NA treated CHB patients received placebo or 2 monthly doses of R07062931 at $0.5 \mathrm{mg} / \mathrm{kg}$, $1.5 \mathrm{mg} / \mathrm{kg}$ or $3.0 \mathrm{mg} / \mathrm{kg}$. A second part of the trial recruited patients to receive R07062931 at $3.0 \mathrm{mg} / \mathrm{kg}$ biweekly for three doses, $3.0 \mathrm{mg} / \mathrm{kg}$ weekly for five doses or $4.0 \mathrm{mg} / \mathrm{kg}$ weekly for four doses. All patients dosed with $0.5 \mathrm{mg} / \mathrm{kg}$ to $3.0 \mathrm{mg} / \mathrm{kg}$ doses had dose-dependent and time-dependent $\mathrm{HBsAg}$ reduction, although dose-dependence was not observed in the $4.0 \mathrm{mg} / \mathrm{kg}$ arm, possibly due to small sample size. The greatest $\mathrm{HBsAg}$ decline of $0.50 \mathrm{log} \mathrm{IU} / \mathrm{mL}$ was observed in the $3.0 \mathrm{~m} / \mathrm{kg}$ weekly arm. All patients in treatment arms had HBsAg nadir 2 weeks after starting treatment, with levels returning to baseline within 12 weeks post-treatment. R07062931 was safe and well-tolerated. ${ }^{68}$ The development of R07062931 was halted due to suboptimal magnitude of HBsAg reduction despite established target engagement.

GSK3389404 is a subcutaneous GalNAc-conjugated 2'-Omethoxyethyl gapmer ASO targeting the HBV X ORF. In a phase II trial, NA treated patients were given GSK3389404 at $60 \mathrm{mg}$ weekly, $120 \mathrm{mg}$ biweekly or $120 \mathrm{mg}$ weekly for 12 weeks. $\mathrm{HBsAg}$ reduction was dose-dependent, with $\mathrm{HBsAg}$ decline of $0.34 \log \mathrm{IU} / \mathrm{mL}, 0.44 \log \mathrm{IU} / \mathrm{mL}$, and $0.75 \mathrm{log} \mathrm{IU} / \mathrm{mL}$ in the $60 \mathrm{mg}$ weekly, $120 \mathrm{mg}$ biweekly group, and $120 \mathrm{mg}$ weekly groups respectively. HBsAg levels returned to baseline within 12 weeks post-treatment. ${ }^{93}$ Similar to R07062931, the modest HBsAg reduction effects precluded future development of GSK3389404.
Bepirovirsen (GSK3228836) is the unconjugated version of GSK3389404 that can be administered subcutaneously. A phase II trial recruited 24 treatment-naïve patients to have placebo, $150 \mathrm{mg}$ bepirovirsen or $300 \mathrm{mg}$ bepirovirsen; with initiation of NA after the first month. The trial also recruited seven NA treated patients to receive placebo or $300 \mathrm{mg}$ bepirovirsen. Bepirovirsen was administered across four weeks (twice weekly for 2 weeks, then weekly for 2 weeks), with subsequent follow-up for 26 weeks. In the treatmentnaïve group, $150 \mathrm{mg}$ bepirovirsen and $300 \mathrm{mg}$ bepirovirsen led to end-treatment mean $\mathrm{HBsAg}$ reduction by $0.50 \mathrm{log} \mathrm{IU} / \mathrm{mL}$ and $1.56 \log \mathrm{IU} / \mathrm{mL}$, respectively. In the treatment-experienced $300 \mathrm{mg}$ bepirovirsen group, the mean $\mathrm{HBsAg}$ reduction was $1.99 \log \mathrm{IU} / \mathrm{mL}$. Two treatment-naïve patients and two treatment-experienced patients, all given $300 \mathrm{mg}$ bepirovirsen, achieved transient unquantifiable $\mathrm{HBsAg}$, with the durability of unquantifiable HBsAg lasting for 57 to 126 days after treatment initiation. Bepirovirsen was well-tolerated. Most treatment-emergent adverse events were mild injection site reactions. Transient self-resolving ALT flares which coincided with $\mathrm{HBsAg}$ reduction were noted in the treatment arms, suggesting immune clearance of infected hepatocytes. $^{94}$

ALG-020572, a GalNAc-conjugated ASO targeting the $S$ ORF, demonstrated rapid absorption and distribution in mice. After administration of ALG-020572 in 3-day intervals in mice for seven doses, dose-dependent HBsAg reduction was demonstrated, with a maximum of $1.1 \log \mathrm{IU} / \mathrm{mL}$ HBsAg reduction in the $10 \mathrm{mg} / \mathrm{kg} \mathrm{ALG}-020572 \mathrm{arm}$. Pharmacokinetic studies in 
non-human primates demonstrated ALG-020572 to have an intrahepatic half-life of 12 days, supporting a weekly regimen in humans. ALG-020572 is currently evaluated in phase I clinical trials.

\section{Combination therapy}

Combination regimens involving RNAi have also been studied, as RNAi alone have not demonstrated consistent HBsAg seroclearance effects in current trials. Combination regimens aim to target different steps of the HBV lifecycle to lead to synergistic antiviral effects.

VIR-2218 has been tested in combination with pegylated interferon alpha-2a. The combination trial recruited NA treated patients to receive 6 monthly doses of $200 \mathrm{mg}$ VIR-2218 along with varying regimens of pegylated interferon alpha$2 a$ in different trial arms. Ninety-two percent of patients in all VIR-2218 arms (with or without interferon) achieved HBsAg below $100 \mathrm{IU} / \mathrm{mL}$ by week 24. Concurrent initiation of VIR2218 and interferon achieved the highest $\mathrm{HBsAg}$ reduction by $2.55 \mathrm{log} \mathrm{IU} / \mathrm{mL}$ at end of treatment, whereas HBsAg decline was relatively less pronounced in patients with VIR-2218 monotherapy (1.89 log IU/mL) or with add-on interferon after VIR-2218 (2.03 log IU/mL). Among the 37 patients on combination therapy, three patients (8.1\%) had unquantifiable HBsAg at week 24 . Only data up till end of treatment ( 24 weeks) were presented in abstract form in 2021 and the complete results including post-treatment $\mathrm{HBsAg}$ sustainability are pending. ${ }^{95}$ Higher incidences of injection site reactions and flu-like symptoms were documented in interferon-containing arms. One patient discontinued from the trial due to interferon-related depression and the patient recovered after drug discontinuation. ${ }^{95}$

The REEF-1 trial is a 48-week trial which recruited NA treated patients to test the combination of JNJ-3989 with the capsid assembly modulator JNJ-6379. Patients in the REEF-1 trial were randomized to receive capsid assembly modulator (250 mg JNJ-6379) monotherapy, JNJ-3989 monotherapy at 40 $\mathrm{mg} / 100 \mathrm{mg} / 200 \mathrm{mg}$, or combination of $100 \mathrm{mg} \mathrm{JNJ}-3989$ plus capsid assembly modulator (250 mg JNJ-6379). JNJ-3989 was administered at monthly doses for 48 weeks. The capsid assembly modulator was given daily for 48 weeks. HBsAg decline was dependent on dosage of JNJ-3989. In the $200 \mathrm{mg}$ JNJ-3989 group, $74.7 \%$ of patients achieved HBsAg below $100 \mathrm{IU} / \mathrm{mL}$, and the group had mean $\mathrm{HBsAg}$ reduction of 2.6 $\log \mathrm{IU} / \mathrm{mL}$. Capsid assembly modulator monotherapy only led to HBsAg decline by $0.07 \log \mathrm{IU} / \mathrm{mL}$, whereas the combination group (100mg JNJ-3989 plus capsid assembly modulator) achieved $1.8 \mathrm{log} \mathrm{IU} / \mathrm{mL} \mathrm{HBsAg}$ decline at end of treatment; both of which were lower than the levels achieved by the 200 mg JNJ-3989 group. ${ }^{96}$ At 24 weeks after the end of treatment, the $\mathrm{HBsAg}$ levels had a gradual increasing trend towards baseline, however the $200 \mathrm{mg} J \mathrm{NJ}-3989$ group still had mean HBsAg $1.9 \mathrm{log} \mathrm{IU} / \mathrm{mL}$ lower than baseline. Among patients in the REEF-1 trial, flu-like symptoms were the most common adverse events reported. Five patients were discontinued from the trial, as three patients in capsid assembly modulator containing arms had renal derangement, one patient in the $40 \mathrm{mg} \mathrm{JNJ}-3989 \mathrm{arm}$ had virologic breakthrough, and one patient in the $40 \mathrm{mg}$ JNJ-3989 arm had insomnia. ${ }^{96}$

Novel combination regimens including ALG-125755 (siRNA) + ALG-020572 (ASO), ${ }^{97}$ and ALG-125903 (siRNA) + ALG020579 (ASO) + ALG-010133 (HBsAg transport inhibiting oligonucleotide polymer) ${ }^{98}$ have shown synergistic effects in invitro and in-vivo experiments, and the development of these novel regimens are ongoing. A range of combination trials including siRNA with toll-like receptor agonists, capsid assembly modulators or pegylated interferon are also ongoing and the results are keenly anticipated.

\section{OVERVIEW OF CURRENT EVIDENCE AND CONCLUSION}

Clinical trials have consistently demonstrated siRNA to be safe, with most adverse events being mild injection reactions or flu-like symptoms. ${ }^{76,89,94}$ ALT flares can occur in siRNA therapy, but are usually transient and associated with $\mathrm{HBsAg}$ reduction, suggesting immune reconstitution and elimination of infected hepatocytes. ${ }^{87-89,94}$

siRNA has demonstrated potent HBsAg reduction effects. Among the newer generation siRNA (excluding the older generation ARC-520 and ARB-1467), mean HBsAg suppression by $2-2.5 \log$ is achievable, with over $90 \%$ of patients in high dose treatment arms reaching over $1 \log \mathrm{IU} / \mathrm{mL} \mathrm{HBsAg}$ reduction, and $50-97 \%$ of patients having $\mathrm{HBsAg}$ suppressed to below $100 \mathrm{IU} / \mathrm{mL}^{75,77,8,89} \mathrm{HBsAg}$ reduction in siRNA was sustainable after end of treatment, ${ }^{75,86,89}$ and incidences of HBsAg seroclearance have been documented. ${ }^{83,95}$ Nonetheless it remains unclear whether these potent $\mathrm{HBsAg}$ reduc- 
tion effects can be translated into durable HBsAg seroclearance. Furthermore, larger scale studies comparing HBeAgpositive and -negative patients are required to determine whether the drug effects are generalizable to different $\mathrm{CHB}$ subgroups. The long term data from current trials on different $\mathrm{CHB}$ populations are keenly anticipated.

Multiple dose regimens are the standard for siRNA, as multiple dosing led to higher magnitude of $\mathrm{HBsAg}$ reduction and more sustainable effects than single dosing. ${ }^{83,84,86,89,95,96}$ The current evidence supports monthly administration of siRNA, with AB-729 demonstrating potent effects even in 8 or 12-weekly dosing. ${ }^{86}$ The total dosing duration for siRNA is less well-defined, as different treatment durations (ranging from 2 months to 1 year) were adopted in the current trials. The decision on ideal treatment durations will likely depend on the durability of post-treatment HBsAg suppression, and trials with longer follow-up will be required to monitor for HBsAg seroclearance. These issues have important implications for the future development of RNAi therapy.

Similar to siRNA, ASO is safe and well-tolerated. ${ }^{68,94}$ While siRNA is administered monthly, ASO requires more frequent dosing (weekly or biweekly), reflecting the inherent pharmacokinetic discrepancy between siRNA and ASO. Bepirovirsen showed potent $\mathrm{HBsAg}$ reduction effects and even transiently suppressed $\mathrm{HBsAg}$ to unquantifiable levels in four patients. A potential explanation for this finding is high cumulative dosing, as six doses of $300 \mathrm{mg}$ bepirovirsen were administered within one month in the trial, which was comparatively higher than the dosing in other ASO and siRNA trials. ${ }^{94}$

Before deciding on the necessity of combining RNAi with other novel antivirals to achieve functional cure in all patients, we need to determine the probability of subsequent $\mathrm{HBsAg}$ seroclearance in patients who have achieved low HBsAg levels (e.g., $<100 \mathrm{IU} / \mathrm{mL}$ ) by RNAi. If the HBsAg seroclearance rate is reasonably high in a short period of time after stopping RNAi, we may not need to combine RNAi with other novel agents of different classes. Nevertheless, combination therapy may be necessary for patients who remain to have high HBsAg levels. With the established efficacy and safety of NAs, future RNAi treatment regimens will likely be combined with an NA backbone. Adding a third anti-HBV agent to RNAi and NA may lead to synergistic antiviral effects. As RNAi has potential effects of immune reconstitution, the addition of immunomodulators may further boost the host antiviral immune system. Indeed, combining VIR-2218 and pegylated in- terferon alpha-2a led to greater HBsAg suppression than either agent alone. ${ }^{95}$ The current data suggest that combining siRNA with interferon can yield a synergistic effect. Nonetheless, other combination regimens of siRNA with immunomodulators including siRNA + therapeutic vaccines and siR$\mathrm{NA}+$ Toll-like receptor agonists are investigated in ongoing trials. ${ }^{99}$ Combining siRNA with novel virus-targeting agents has also been investigated. Notably, preclinical experiments demonstrated synergistic effects when combining siRNA and ASO, two RNA silencers that share the same target (mRNA). Although the underlying mechanism and clinical efficacy of this combination is yet to be determined ${ }^{97}$ it would be interesting to determine whether the synergistic effect is related to the full utilization of different RNA degradation pathways as described above. On the other hand, combination of siRNA and capsid assembly modulator has failed to yield synergistic effects in an ongoing trial. ${ }^{96}$ This highlights the need for meticulous selection of combination agents with siRNA, and a range of combination trials involving agents with different mechanisms are ongoing.

To conclude, RNAi is a safe technique that can induce potent and sustainable HBsAg suppression. Research on RNAi is rapidly evolving and early phase data has been promising. Multiple trials are ongoing, and with further development, RNAi may emerge as a novel treatment strategy that shifts the paradigm of $\mathrm{CHB}$ therapy.

\section{Authors' contribution}

RWHH was involved in data interpretation and drafting of the manuscript. LYM and WKS were involved in critical revision of the manuscript. MFY was involved in study concept, critical revision of the manuscript, and overall study supervision. All authors have seen and approved the final version of the manuscript.

\section{Conflicts of Interest}

MF Yuen is an advisory board member and/or received research funding from AbbVie, Arbutus Biopharma, Assembly Biosciences, Bristol Myer Squibb, Dicerna Pharmaceuticals, GlaxoSmithKline, Gilead Sciences, Janssen, Merck Sharp and Dohme, Clear B Therapeutics, Springbank Pharmaceuticals; and received research funding from Arrowhead Pharmaceuticals, Fujirebio Incorporation and Sysmex Corporation. WK Seto received speaker's fees from AstraZeneca and Mylan, is 
an advisory board member of CSL Behring, is an advisory board member and received speaker's fees from AbbVie, and is an advisory board member, received speaker's fees and researching funding from Gilead Sciences. The remaining authors have no conflict of interests.

\section{REFERENCES}

1. Polaris Observatory Collaborators. Global prevalence, treatment, and prevention of hepatitis B virus infection in 2016: a modelling study. Lancet Gastroenterol Hepatol 2018;3:383-403.

2. Seto WK, Lo YR, Pawlotsky JM, Yuen MF. Chronic hepatitis B virus infection. Lancet 2018;392:2313-2324.

3. Mak LY, Seto WK, Hui RW, Fung J, Wong DK, Lai CL, et al. Fibrosis evolution in chronic hepatitis $B$ e antigen-negative patients across a 10-year interval. J Viral Hepat 2019;26:818-827.

4. Yuen MF, Wong DK, Fung J, Ip P, But D, Hung I, et al. HBsAg seroclearance in chronic hepatitis $B$ in Asian patients: replicative level and risk of hepatocellular carcinoma. Gastroenterology 2008;135:1192-1199.

5. Mak LY, Seto WK, Yuen MF. Novel antivirals in clinical development for chronic hepatitis B infection. Viruses 2021;13:1169.

6. Blank A, Markert C, Hohmann N, Carls A, Mikus G, Lehr T, et al. First-in-human application of the novel hepatitis $B$ and hepatitis D virus entry inhibitor myrcludex B. J Hepatol 2016;65:483489.

7. Squires KE, Mayers DL, Bluemling GR, Kolykhalov AA, Guthrie DB, Reddy P, et al. ATI-2173, a novel liver-targeted non-chainterminating nucleotide for hepatitis $B$ virus cure regimens. Antimicrob Agents Chemother 2020;64:e00836-20.

8. Morrissey DV, Lockridge JA, Shaw L, Blanchard K, Jensen K, Breen W, et al. Potent and persistent in vivo anti-HBV activity of chemically modified siRNAs. Nat Biotechnol 2005;23:1002-1007.

9. Hui RWH, Mak LY, Seto WK, Yuen MF. Role of core/capsid inhibitors in functional cure strategies for chronic hepatitis B. Curr Hepatology Rep 2020;19:293-301.

10. Real Cl, Werner M, Paul A, Gerken G, Schlaak JF, Vaillant A, et al. Nucleic acid-based polymers effective against hepatitis $B$ virus infection in patients don't harbor immunostimulatory properties in primary isolated liver cells. Sci Rep 2017;7:43838.

11. Kao CC, Nie Y, Ren S, De Costa NTTS, Pandey RK, Hong J, et al. Mechanism of action of hepatitis $B$ virus $S$ antigen transportinhibiting oligonucleotide polymer, STOPS, molecules. Mol Ther Nucleic Acids 2021;27:335-348.
12. Erken R, Andre P, Roy E, Kootstra N, Barzic N, Girma H, et al. Farnesoid $\mathrm{X}$ receptor agonist for the treatment of chronic hepatitis B: a safety study. J Viral Hepat 2021;28:1690-1698.

13. Boni C, Vecchi A, Rossi M, Laccabue D, Giuberti T, Alfieri A, et al. TLR7 agonist increases responses of hepatitis $B$ virus-specific $T$ cells and natural killer cells in patients with chronic hepatitis B treated with nucleos(t)ide analogues. Gastroenterology 2018;154:1764-1777.e7.

14. Gane E, Verdon DJ, Brooks AE, Gaggar A, Nguyen AH, Subramanian GM, et al. Anti-PD-1 blockade with nivolumab with and without therapeutic vaccination for virally suppressed chronic hepatitis B: a pilot study. J Hepatol 2019;71:900-907.

15. Fergusson JR, Wallace Z, Connolly MM, Woon AP, Suckling RJ, Hine DW, et al. Immune-mobilizing monoclonal T cell receptors mediate specific and rapid elimination of hepatitis B-infected cells. Hepatology 2020;72:1528-1540.

16. Boni C, Janssen HLA, Rossi M, Yoon SK, Vecchi A, Barili V, et al. Combined GS-4774 and tenofovir therapy can improve HBVspecific T-cell responses in patients with chronic hepatitis. Gastroenterology 2019;157:227-241.e7.

17. Lee HW, Park JY, Hong T, Park MS, Ahn SH. A prospective, openlabel, dose-escalation, single-center, phase 1 study for GC1102, a recombinant human immunoglobulin for chronic hepatitis $B$ patients. Hepatology 2018;68(S1):453.

18. Yeo YH, Ho HJ, Yang HI, Tseng TC, Hosaka T, Trinh HN, et al. Factors associated with rates of $\mathrm{HBsAg}$ seroclearance in adults with chronic HBV infection: a systematic review and meta-analysis. Gastroenterology 2019;156:635-646.e9.

19. Fire A, Xu S, Montgomery MK, Kostas SA, Driver SE, Mello CC. Potent and specific genetic interference by double-stranded RNA in Caenorhabditis elegans. Nature 1998;391:806-811.

20. MacRae IJ, Ma E, Zhou M, Robinson CV, Doudna JA. In vitro reconstitution of the human RISC-loading complex. Proc Natl Acad Sci U S A 2008;105:512-517.

21. Caplen NJ, Parrish S, Imani F, Fire A, Morgan RA. Specific inhibition of gene expression by small double-stranded RNAs in invertebrate and vertebrate systems. Proc Natl Acad Sci U S A 2001;98:9742-9747.

22. Rivas FV, Tolia NH, Song JJ, Aragon JP, Liu J, Hannon GJ, et al. Purified argonaute 2 and an siRNA form recombinant human RISC. Nat Struct Mol Biol 2005;12:340-349.

23. Iwasaki S, Kawamata T, Tomari Y. Drosophila argonaute1 and argonaute2 employ distinct mechanisms for translational repression. Mol Cell 2009;34:58-67.

24. Petersen CP, Bordeleau ME, Pelletier J, Sharp PA. Short RNAs 
repress translation after initiation in mammalian cells. Mol Cell 2006;21:533-542.

25. Verdel A, Jia S, Gerber S, Sugiyama T, Gygi S, Grewal SI, et al. RNAi-mediated targeting of heterochromatin by the RITS complex. Science 2004;303:672-676.

26. Haley B, Zamore PD. Kinetic analysis of the RNAi enzyme complex. Nat Struct Mol Biol 2004;11:599-606.

27. Adams D, Gonzalez-Duarte A, O'Riordan WD, Yang CC, Ueda M, Kristen AV, et al. Patisiran, an RNAi therapeutic, for hereditary transthyretin amyloidosis. N Engl J Med 2018;379:11-21.

28. Setten RL, Rossi JJ, Han SP. The current state and future directions of RNAi-based therapeutics. Nat Rev Drug Discov 2019;18: 421-446.

29. Jacque JM, Triques K, Stevenson M. Modulation of HIV-1 replication by RNA interference. Nature 2002;418:435-438.

30. Kumar P, Ban HS, Kim SS, Wu H, Pearson T, Greiner DL, et al. T cell-specific siRNA delivery suppresses HIV-1 infection in humanized mice. Cell 2008;134:577-586.

31. Bitko V, Barik S. Phenotypic silencing of cytoplasmic genes using sequence-specific double-stranded short interfering RNA and its application in the reverse genetics of wild type negative-strand RNA viruses. BMC Microbiol 2001;1:34.

32. Gitlin L, Stone JK, Andino R. Poliovirus escape from RNA interference: short interfering RNA-target recognition and implications for therapeutic approaches. J Virol 2005;79:1027-1035.

33. Geisbert TW, Lee AC, Robbins M, Geisbert JB, Honko AN, Sood V, et al. Postexposure protection of non-human primates against a lethal Ebola virus challenge with RNA interference: a proof-ofconcept study. Lancet 2010;375:1896-1905.

34. Levanova A, Poranen MM. RNA interference as a prospective tool for the control of human viral infections. Front Microbiol 2018;9:2151.

35. Jackson AL, Linsley PS. Recognizing and avoiding siRNA offtarget effects for target identification and therapeutic application. Nat Rev Drug Discov 2010;9:57-67.

36. Qiu S, Adema CM, Lane T. A computational study of off-target effects of RNA interference. Nucleic Acids Res 2005;33:18341847.

37. Naito $Y$, Ui-Tei K. siRNA design software for a target genespecific RNA interference. Front Genet 2012;3:102.

38. Hickerson RP, Vlassov AV, Wang Q, Leake D, Ilves H, GonzalezGonzalez E, et al. Stability study of unmodified siRNA and relevance to clinical use. Oligonucleotides 2008;18:345-354.

39. Liao $\mathrm{H}$, Wang JH. Biomembrane-permeable and ribonucleaseresistant siRNA with enhanced activity. Oligonucleotides
2005;15:196-205.

40. Sledz CA, Holko M, de Veer MJ, Silverman RH, Williams BR. Activation of the interferon system by short-interfering RNAs. Nat Cell Biol 2003;5:834-839.

41. Alexopoulou L, Holt AC, Medzhitov R, Flavell RA. Recognition of double-stranded RNA and activation of NF-kappaB by toll-like receptor 3. Nature 2001;413:732-738.

42. Czauderna F, Fechtner M, Dames S, Aygün H, Klippel A, Pronk $\mathrm{GJ}$, et al. Structural variations and stabilising modifications of synthetic siRNAs in mammalian cells. Nucleic Acids Res 2003;31: 2705-2716.

43. Jackson AL, Burchard J, Leake D, Reynolds A, Schelter J, Guo J, et al. Position-specific chemical modification of siRNAs reduces "off-target" transcript silencing. RNA 2006;12:1197-1205.

44. Judge AD, Bola G, Lee AC, MacLachlan I. Design of noninflammatory synthetic siRNA mediating potent gene silencing in vivo. Mol Ther 2006;13:494-505.

45. Allerson CR, Sioufi N, Jarres R, Prakash TP, Naik N, Berdeja A, et al. Fully 2'-modified oligonucleotide duplexes with improved in vitro potency and stability compared to unmodified small interfering RNA. J Med Chem 2005;48:901-904.

46. Shen C, Reske SN. Adenovirus-delivered siRNA. Methods Mol Biol 2004;252:523-532.

47. Kaczmarek JC, Kowalski PS, Anderson DG. Advances in the delivery of RNA therapeutics: from concept to clinical reality. Genome Med 2017;9:60.

48. Springer AD, Dowdy SF. GalNAc-siRNA conjugates: leading the way for delivery of RNAi therapeutics. Nucleic Acid Ther 2018;28:109-118.

49. Konishi M, Wu CH, Wu GY. Inhibition of HBV replication by siRNA in a stable HBV-producing cell line. Hepatology 2003;38:842850.

50. Boden D, Pusch O, Lee F, Tucker L, Ramratnam B. Human immunodeficiency virus type 1 escape from RNA interference. J Virol 2003;77:11531-11535.

51. Kapadia SB, Brideau-Andersen A, Chisari FV. Interference of hepatitis $C$ virus RNA replication by short interfering RNAs. Proc Natl Acad Sci U S A 2003;100:2014-2018.

52. Buti M, Rodriguez-Frias F, Jardi R, Esteban R. Hepatitis B virus genome variability and disease progression: the impact of precore mutants and HBV genotypes. J Clin Virol 2005;34 Suppl 1:S79-S82.

53. Wu HL, Huang LR, Huang CC, Lai HL, Liu CJ, Huang YT, et al. RNA interference-mediated control of hepatitis $B$ virus and emergence of resistant mutant. Gastroenterology 2005;128:708-716. 
54. Shih YM, Sun CP, Chou HH, Wu TH, Chen CC, Wu PY, et al. Combinatorial RNA interference therapy prevents selection of preexisting HBV variants in human liver chimeric mice. Sci Rep 2015;5:15259.

55. Kayesh MEH, Kohara M, Tsukiyama-Kohara K. Toll-like receptor response to hepatitis $B$ virus infection and potential of TLR agonists as immunomodulators for treating chronic hepatitis $B$ : an overview. Int J Mol Sci 2021;22:10462.

56. Fisicaro P, Valdatta C, Massari M, Loggi E, Biasini E, Sacchelli L, et al. Antiviral intrahepatic T-cell responses can be restored by blocking programmed death-1 pathway in chronic hepatitis B. Gastroenterology 2010;138:682-693, 693.e1-e4.

57. Stoop JN, van der Molen RG, Baan CC, van der Laan LJ, Kuipers EJ, Kusters JG, et al. Regulatory T cells contribute to the impaired immune response in patients with chronic hepatitis $B$ virus infection. Hepatology 2005;41:771-778.

58. Le Bert N, Gill US, Hong M, Kunasegaran K, Tan DZM, Ahmad R, et al. Effects of hepatitis $B$ surface antigen on virus-specific and global T cells in patients with chronic hepatitis B virus infection. Gastroenterology 2020;159:652-664.

59. Park JJ, Wong DK, Wahed AS, Lee WM, Feld JJ, Terrault N, et al. Hepatitis B virus--specific and global T-cell dysfunction in chronic hepatitis B. Gastroenterology 2016;150:684-695.e5.

60. Seto WK, Cheung KS, Wong DK, Huang FY, Fung J, Liu KS, et al. Hepatitis B surface antigen seroclearance during nucleoside analogue therapy: surface antigen kinetics, outcomes, and durability. J Gastroenterol 2016;51:487-495.

61. Boni C, Laccabue D, Lampertico P, Giuberti T, Viganò $M$, Schivazappa S, et al. Restored function of HBV-specific T cells after long-term effective therapy with nucleos(t)ide analogues. Gastroenterology 2012;143:963-973.e9.

62. Sohail M, Hochegger H, Klotzbücher A, Guellec RL, Hunt T, Southern EM. Antisense oligonucleotides selected by hybridisation to scanning arrays are effective reagents in vivo. Nucleic Acids Res 2001;29:2041-2051.

63. Dhuri K, Bechtold C, Quijano E, Pham H, Gupta A, Vikram A, et al. Antisense oligonucleotides: an emerging area in drug discovery and development. J Clin Med 2020;9:2004.

64. Miller CM, Tanowitz M, Donner AJ, Prakash TP, Swayze EE, Harris EN, et al. Receptor-mediated uptake of phosphorothioate antisense oligonucleotides in different cell types of the liver. Nucleic Acid Ther 2018;28:119-127.

65. Dominska M, Dykxhoorn DM. Breaking down the barriers: siRNA delivery and endosome escape. J Cell Sci 2010;123(Pt 8):1183-1189.
66. Vocelle D, Chan C, Walton SP. Endocytosis controls siRNA efficiency: implications for siRNA delivery vehicle design and cellspecific targeting. Nucleic Acid Ther 2020;30:22-32.

67. Linnane E, Davey P, Zhang P, Puri S, Edbrooke M, Chiarparin E, et al. Differential uptake, kinetics and mechanisms of intracellular trafficking of next-generation antisense oligonucleotides across human cancer cell lines. Nucleic Acids Res 2019;47:43754392.

68. Gane E, Yuen MF, Kim DJ, Chan HL, Surujbally B, Pavlovic V, et al. Clinical study of single-stranded oligonucleotide R07062931 in healthy volunteers and patients with chronic hepatitis B. Hepatology 2021;74:1795-1808.

69. Liang XH, Sun H, Nichols JG, Crooke ST. RNase H1-dependent antisense oligonucleotides are robustly active in directing RNA cleavage in both the cytoplasm and the nucleus. Mol Ther 2017;25:2075-2092.

70. Liang XH, Sun H, Shen W, Wang S, Yao J, Migawa MT, et al. Antisense oligonucleotides targeting translation inhibitory elements in $5^{\prime}$ UTRs can selectively increase protein levels. Nucleic Acids Res 2017;45:9528-9546.

71. Tallet-Lopez B, Aldaz-Carroll L, Chabas S, Dausse E, Staedel C, Toulmé JJ. Antisense oligonucleotides targeted to the domain IIId of the hepatitis C virus IRES compete with 40 S ribosomal subunit binding and prevent in vitro translation. Nucleic Acids Res 2003:31:734-742.

72. Goodarzi G, Gross SC, Tewari A, Watabe K. Antisense oligodeoxyribonucleotides inhibit the expression of the gene for hepatitis B virus surface antigen. J Gen Virol 1990;71(Pt 12):30213025.

73. Wooddell Cl, Rozema DB, Hossbach M, John M, Hamilton HL, Chu Q, et al. Hepatocyte-targeted RNAi therapeutics for the treatment of chronic hepatitis B virus infection. Mol Ther 2013; 21:973-985.

74. Wooddell Cl, Yuen MF, Chan HL, Gish RG, Locarnini SA, Chavez D, et al. RNAi-based treatment of chronically infected patients and chimpanzees reveals that integrated hepatitis $B$ virus DNA is a source of HBsAg. Sci Transl Med 2017;9:eaan0241.

75. Gane E, Lim YS, Cloutier D, Shen L, Cathcart A, Ding X, et al. Safety and antiviral activity of VIR-2218, an X-targeting RNAi therapeutic, in participants with chronic hepatitis $B$ infection: week 48 follow-up results. J Hepatol 2021;75:S287-S288.

76. Sterinu-Cercel A, Gane E, Cheng W, Sievert W, Roberts S, Ahn $\mathrm{SH}$, et al. A phase 2a study evaluating the multi-dose activity of ARB-1467 in HBeAg-positive and -negative virally suppressed subjects with hepatitis B. J Hepatol 2017;66:S688-S689. 
77. Gane E, Locarnini S, Lim TH, Strasser S, Sievert W, Cheng W, et al. Short interfering RNA JNJ-3989 combination therapy in chronic hepatitis $B$ shows potent reduction of all viral markers but no correlate was identified for $\mathrm{HBsAg}$ reduction and baseline factors. J Hepatol 2021;75(Suppl 2):S289-S290.

78. Thi EP, Dhillon AP, Ardzinski A, Bidirici-Ertekin L, Cobarrubias KD, Cuconati A, et al. ARB-1740, a RNA interference therapeutic for chronic hepatitis B infection. ACS Infect Dis 2019;5:725-737.

79. Wooddell C, Zhu R, Hamilton H, Chu Q, Sternard H, Schumacher $J$, et al. Development of subcutaneously administered RNAi therapeutic ARO-HBV for chronic hepatitis B virus infection. J Hepatol 2018;68:S18-S19.

80. Durantel D, Zoulim F. New antiviral targets for innovative treatment concepts for hepatitis B virus and hepatitis delta virus. J Hepatol 2016;64(1 Suppl):S117-S131.

81 Schluep T, Lickliter J, Hamilton J, Lewis DL, Lai CL, Lau JY, et al. Safety, tolerability, and pharmacokinetics of ARC-520 injection, an RNA interference-based therapeutic for the treatment of chronic hepatitis $B$ virus infection, in healthy volunteers. Clin Pharmacol Drug Dev 2017;6:350-362.

82. Yuen MF, Schiefke I, Yoon JH, Ahn SH, Heo J, Kim JH, et al. RNA interference therapy with ARC-520 results in prolonged hepatitis $B$ surface antigen response in patients with chronic hepatitis B infection. Hepatology 2020;72:19-31.

83. Yuen MF, Wong DK, Schluep T, Lai CL, Ferrari C, Locarnini S, et al. Long-term serological, virological and histological responses to RNA inhibition by ARC-520 in Chinese chronic hepatitis B patients on entecavir treatment. Gut 2022;71:789-797.

84. Agarwal K, Gane E, Cheng W, Sievert W, Roberts S, Ahn SH, et al. Bi-weekly dosing of ARB-1467 LNP siRNA in HBeAgNegative, virally suppressed patients with chronic $\mathrm{HBV}$ infection leads to deeper declines in HBsAg and potential association with IL28b. AASLD The Liver Meeting 2017; 2017 Oct 20-24; Washington, DC, USA.

85. Arbutus Biopharma. Arbutus reports fourth quarter and yearend 2018 financial results and describes recent clinical accomplishments and key 2019 objectives. Arbutus Biopharma web site, <https://investor.arbutusbio.com/news-releases/newsrelease-details/arbutus-reports-fourth-quarter-and-year-end2018-financial>. Accessed 15 Feb 2022.

86. Yuen MF, Berliba E, Sukeepaisarnjaroen W, Tangkijvanich P, Leerapun A, Holmes J, et al. Low HBsAg levels maintained following cessation of the GalNAc-siRNA, AB-729, in chronic hepatitis $B$ patients on nucleos(t)ide analogue therapy. AASLD The Liver Meeting; 2021 Nov 12-15; USA.
87. Thi EP, Yuen MF, Gane E, Sevinsky H, Sims K, Anderson M, et al. Inhibition of hepatitis $B$ surface antigen by RNA interference therapeutic AB-729 in chronic hepatitis B patients correlates with suppression of all HBsAg isoforms and HBV RNA. J Hepatol 2021;75:S760.

88. Paratala BS, Park JJ, Ganchua SC, Gane E, Yuen MF, Lee ACH, et al. Inhibition of hepatitis $B$ surface antigen in chronic hepatitis $B$ subjects by RNA interference therapeutic AB-729 is accompanied by upregulation of HBV-specific T cell activation markers. J Hepatol 2021;75:S761.

89. Yuen MF, Lim TH, Kim W, Tongkijvonich P, Yoon JH, Sievert W, et al. HBV RNAi inhibitor RG6346 in Phase 1b-2a trial was safe, well tolerated, and resulted in substantial and durable reductions in serum HBsAg levels. AASLD The Liver Meeting; 2020 Nov 11-16; USA.

90. Hong J, Montero SM, Tan H, Rajwanshi VK, Kang H, Sousa J, et al. Incorporation of novel siRNA chemistries significantly improves the potency and durability of HBV siRNAs in the AAV-HBV mouse model. AASLD The Liver Meeting; 2021 Nov 12-15; USA.

91. Hong J, Montero SM, De Costa T, Nie Y, Tan H, Pandey R, et al. ALG-125755, a small interfering RNA (siRNA) against hepatitis $B$ virus (HBV) effectively inhibits hepatitis $B$ surface antigen (HBsAg) secretion in HBV cell models and the AAV-HBV mouse model. J Hepatol 2021;75:S742.

92. Aligos Therapeutics. Aligos Therapeutics to present phase 1 safety and pharmacokinetic data for STOPS ${ }^{\text {TM }}$ molecule drug candidate ALG-010133 and several nonclinical chronic hepatitis B programs at the european association for the study of the Liver's Digital International Liver Congress 2021. Aligos Therapeutics web site, <https://www.globenewswire.com/ news-release/2021/06/21/2250190/0/en/Aligos-Therapeuticsto-Present-Phase-1-Safety-and-Pharmacokinetic-Data-forSTOPS-Molecule-Drug-Candidate-ALG-010133-and-SeveralNonclinical-Chronic-Hepatitis-B-Programs-at-the-Euro.html>. Accessed 15 Feb 2022.

93. Yuen MF, Heo J, Kumada H, Suzuki F, Suzuki Y, Xie Q, et al. Results after 12 weeks treatment of multiple doses of GSK3389404 in chronic hepatitis $B(C H B)$ subjects on stable nucleos(t)ide therapy in a phase 2a double-blind, placebo-controlled study. AASLD The Liver Meeting; 2019 Nov 8-11; Boston, USA.

94. Yuen MF, Heo J, Jang JW, Yoon JH, Kweon YO, Park SJ, et al. Safety, tolerability and antiviral activity of the antisense oligonucleotide bepirovirsen in patients with chronic hepatitis $B$ : a phase 2 randomized controlled trial. Nat Med 2021;27:1725-1734.

95. Yuen MF, Lim YS, Cloutier D, Thanawala V, Shen L, Arizpe A, et 
al. Preliminary results from a phase 2 study evaluating VIR-2218 alone and in combination with pegylated interferon Alfa-2a in participants with chronic hepatitis B infection. AASLD The Liver Meeting; 2021 Nov 12-15; USA.

96. Yuen MF, Asselah T, Jacobson IM, Brunetto M, Janssen HL, Takehara T, et al. Efficacy and safety of the siRNA JNJ-3989 and/or the capsid assembly modulator JNJ-6379 for the treatment of chronic hepatitis $B$ virus infection: results from the phase $2 b$ REEF-1 study. AASLD The Liver Meeting; 2021 Nov 12-15; USA.

97. Tan H, Kang H, Luo M, Nie Y, Pandey R, Montero SM, et al. Combination drug interactions of hepatitis $B$ virus (HBV) small interfering RNA (siRNA) and antisense oligonucleotides (ASO) in vitro and in vivo. J Hepatol 2021;75:S720.

98. Tan H, Kang H, Hong J, Luo M, Nie Y, Pandey R, et al. Triple combination of anti-hepatitis $B$ virus drugs demonstrates synergistic activity in vitro. AASLD The Liver Meeting; 2021 Nov 12-15; USA.

99. Michler T, Kosinska AD, Festag J, Bunse T, Su J, Ringelhan M, et al. Knockdown of virus antigen expression increases therapeutic vaccine efficacy in high-titer hepatitis $B$ virus carrier mice. Gastroenterology 2020;158:1762-1775.e9. 